\title{
Bilirubin Toxicity in Neural Cell Lines N115 and NBR10A
}

\author{
DAVID SCHIFF, GEORGE CHAN, AND MARK J. POZNANSKY \\ Departments of Pediatrics and Physiology, 2C300 Walter MacKenzie Health Sciences Center, University of \\ Alberta, Edmonton, Alberta, Canada T6G $2 B 7$
}

\begin{abstract}
The toxicity of bilirubin was investigated in 2 neural cell lines NBR10A and N115 using a quantitative dye assay 3-(4,5 dimethylthiazol-2-yl)-2,5-diphenyl tetrazolium biomide (MTT) as a measure of cell viability and $\left[{ }^{3} \mathrm{H} \mid\right.$ thymidine incorporation as a measure of DNA synthesis. Short exposures (up to $2 \mathrm{~h}$ ) to bilirubin, even up to a bilirubin-albumin molar ratio of 1.5, yielded no evidence of toxicity using these assays. At longer exposure times (24 h) a decrease in cell viability and $\left.{ }^{3} \mathrm{H}\right]$ thymidine incorporation was detected at a molar ratio of 0.8 when the bilirubin concentration was $0.1 \mathrm{mM}$ or higher, whereas lower bilirubin levels at this molar ratio showed no deleterous effect. The effect of bilirubin is more pronounced at a molar ratio of 1.5 with longer incubation periods. The MTT assay showed the N115 cells appeared to be more resistant to bilirubin cytotoxicity than NBR10A cells, a finding which was not obtained from $\left[{ }^{3} \mathrm{H}\right]$ thymidine incorporation studies. This discrepancy can be explained by the fact that we are measuring two different variables; the MTT assay estimates the number of viable cells at the end of the experiment by measuring mitochondrial function whereas the ${ }^{3} \mathbf{H} \mid$ thymidine assay measures the rate of DNA synthesis during the last $2 h$ of the experiment. The concentration effect of bilirubin is evident from the $\left[{ }^{3} \mathrm{H}\right]-$ thymidine studies in that at a molar ratio of 1.5 and bilirubin concentration of $0.075 \mathrm{mM}$ or higher, there is both cell kill (decrease in DNA) and inhibition of $\left.{ }^{3} \mathrm{H}\right]-$ thymidine incorporation (decrease in specific activity). When the bilirubin concentration is reduced to $0.03 \mathrm{mM}$, there is little or no cell death (no change DNA) but inhibition still exists (42\% decrease in specific activity). Thus, cell viability and function of these two neural lines is dependent not only on the bilirubin albumin molar ratio, but also on the absolute concentration of bilirubin and albumin as well as the time of exposure. (Pediatr Res 19: 908-911, 1985)
\end{abstract}

\section{Abbreviations}

MTT, 3-(4,5 dimethylthiazol-y-yl)-2,5-diphenyl tetrazolium bromide

DMEM, Dulbecco modified Eagle's medium

PBS, phosphate-buffered saline

Hyperbilirubinemia is a common occurrence in the newborn period, particularly in premature infants, and it has been asso-

Received July 26, 1984: accepted April 17. 1985.

Requests for reprints should be addressed to Dr. David Schiff, Department of Pediatrics. University of Alberta. 2C 300 Walter Mackenzie Health Sciences Center. Edmonton, Alberta, Canada, T6G 2B7.

Supported by a grant from Central Research Fund. University of Alberta to D. S. and the Medical Research Council of Canada to M. J. P. ciated with irreversible nuclear damage in the brain (kernicterus) (1). The toxic effect of bilirubin in tissue culture cells have been reported in a number of studies including histologic damage in dissociated rat cerebellum (2), decrease in glucose consumption in human fibroblasts (3), decrease in viability and ATP content (4), and increase in potassium leakage in modified L-929 mouse fibroblasts (5). Thaler (6) reported a decrease in DNA synthesis in hepatoma cells. Cell viability in most of these studies was assessed by the exclusion of either trypan blue or erythrocin B. The dyes will only stain those cells which are nonviable and leaky. A qualitative assessment of viable to nonviable cells is usually done by counting under the microscope.

To our knowledge, no studies have been done on the cytotoxicity of bilirubin on neural cell lines in culture. In the present study, we evaluate the effects of bilirubin in the presence or absence of albumin on cytotoxicity in two established neural cell lines, namely N115, a rat neuroblastoma cell and NBR 10A a murine neuroblastoma hybrid cell line.

Cell viability is determined by the ability of active mitochondria to cleave a yellow dye, MTT, to form a dark blue formazan. The amount of dye incorporated is proportional to the number of viable cells. Even freshly dead cells would not cleave MTT (7). This provides a method in which the toxic effects of bilirubin on tissue culture cells can be quantitatively assessed. The incorporation of $\left[{ }^{3} \mathrm{H}\right]$ thymidine into DNA and total DNA levels are also studied in these 2 cell lines under the same conditions as MTT assay, thereby allowing comparison of similarities and differences of these two approaches.

\section{MATERIALS AND METHODS}

MTT assay. N115 cells are grown in standard DMEM plus $8 \%$ fetal calf serum, and NBR 10A cells are grown in DMEM plus $8 \%$ fetal calf serum, plus a HAT supplement (hypoxanthine $136 \mathrm{mg} /$ liter, aminopteryine at $1.8 \mathrm{mg} /$ liter, thymidine at 72.6 $\mathrm{mg} / \mathrm{liter}$ ) in $6 \mathrm{~cm}$ culture dishes at $37^{\circ} \mathrm{C}$ in a $5 \% \mathrm{CO}_{2}$ humidified atmosphere. Cells $(5000 /$ well) are then seeded in 96-well flat bottomed tissue culture trays of good optical quality (e.g. Falcon). Final volume of media in each well is $100 \mu \mathrm{l}$. The cells are adapted to grow in a protein free media (8) for $24 \mathrm{~h}$ before the experiments with bilirubin are set up.

A stock solution of human serum albumin (fraction $V$ essentially free fatty acid free, Sigma) is made up at a concentration of $1 \mathrm{mM}$ in DMEM and sterilized by filtration. Immediately before use, a stock solution of $10 \mathrm{mM}$ of bilirubin (lot number 13F0846) obtained from Sigma was verified by high-pressure liquid chromatography to contain $92 \%$ of the IX $\alpha$ moiety and the rest being $\mathrm{X} 111 \alpha$ and $111 \alpha$. No other bile pigments were detected and the bilirubin preparation was used in the experiments without further purification and was made up by dissolving $5.85 \mathrm{mg}$ of bilirubin in $0.5 \mathrm{ml} 0.1 \mathrm{~N} \mathrm{NaOH}$. Once bilirubin is in solution, $0.5 \mathrm{ml}$ of diluent at $\mathrm{pH} 7.8$ containing $0.45 \% \mathrm{NaCl}$ and $0.45 \% \mathrm{Na}_{2} \mathrm{CO}_{3}$ is added. The bilirubin and albumin solutions are mixed in various volumes to achieve bilirubin to 
albumin molar ratio of 0 to 1.5 with albumin concentration varying from 0.2 to $0.01 \mathrm{mM}$ and bilirubin levels to $0.3 \mathrm{mM}$ to 0 (control). Twenty-five microliters of each solution is added to $100 \mu \mathrm{l}$ of protein-free media per well. A minimum of eight wells is used under each test condition.

MTT (Sigma) made up as a $5 \mathrm{mg} / \mathrm{ml}$ solution in PBS ( $\mathrm{pH} 7.4$ ) is then filtered to sterilize. This yellow solution is stable for several weeks when stored in the dark at $4^{\circ} \mathrm{C}$. Just before use, one part MTT is mixed with nine parts of protein-free media.

After incubation for 2 and $24 \mathrm{~h}$, respectively, the media containing bilirubin is removed by suction, replaced with fresh media containing MTT (see above) with a multichannel pipettor and incubated for another $2 \mathrm{~h}$. The cleaved dye which can now be seen as fuzzy blue crystals at the bottom of the well is dissolved in $100 \mu \mathrm{l}$ of isopropanol- $\mathrm{HCl}(0.04 \mathrm{~N})$ by agitation with repeated pipetting with a multichannel pipettor until a blue solution is obtained. The absorbances of the individual wells is then read in a multichannel plate reader with a test wavelength of 570 $\mathrm{nm}$ and a reference wavelength of $630 \mathrm{~nm}$.

${ }^{3}$ H]thymidine incorporation into DNA. For the experiments with $\left[{ }^{3} \mathrm{H}\right]$ thymidine incorporation into DNA the cells are seeded at a concentration of $1 \times 10^{5}$ cells on $3-\mathrm{cm}$ culture dishes and allowed to grow in standard DMEM for $24 \mathrm{~h}$. The media is then removed by suction and replaced with $2 \mathrm{ml}$ protein-free experimental media (see above) for a further $24 \mathrm{~h}$. Stock solutions of albumin $(1 \mathrm{mM})$ and bilirubin $(10 \mathrm{mM})$ are prepared as previously described. The bilirubin albumin preparations, $0.5 \mathrm{ml}$, are added to the media, mixed gently, and incubated for 2 and 24 $h$. The cells are then pulse labeled with $\left[{ }^{3} \mathrm{H}\right]$ thymidine (NEN), 1 $\mu \mathrm{Ci}$ per dish for $2 \mathrm{~h}$. Triplicate analysis are performed for each experimental condition. At the end of the incubation period the medium is removed and the cells washed three times with PBS. The cells are suspended in $1 \mathrm{ml}$ PBS then scraped off with a rubber policeman and pipetted into an eppendorf test tube with a Pasteur pipet. After a brief centrifugation, the supernatant is suctioned off and replaced with $0.4 \mathrm{ml}$ PBS. The cells are fragmented by sonication with a microprobe for $5 \mathrm{sec}$. Two hundred microliters are removed for counting using ACS as the scintillant. The remainder is used for DNA estimation (9). The incorporation of $\left[{ }^{3} \mathrm{H}\right]$ thymidine is expressed as $\mathrm{cpm} / \mu \mathrm{g}$ DNA. The $\mathrm{pH}$ and bilirubin (10) level in the media were monitored at 0,2 , and $24 \mathrm{~h}$ respectively, in the presence or absence of cells.

\section{RESULTS}

MTT assay. Both the NBR10A and N115 cell lines seem to be very resistant to the toxic effects of bilirubin at bilirubinalbumin molar ratios of 1 or less for incubations of up to $24 \mathrm{~h}$. Beyond a bilirubin/albumin molar ratio of 1 , percentage viability decreases to a minimum of $20 \%$ of control at bilirubin/albumin molar ratio of 1.5 (Fig. 1). Figure 2 shows the effect of different

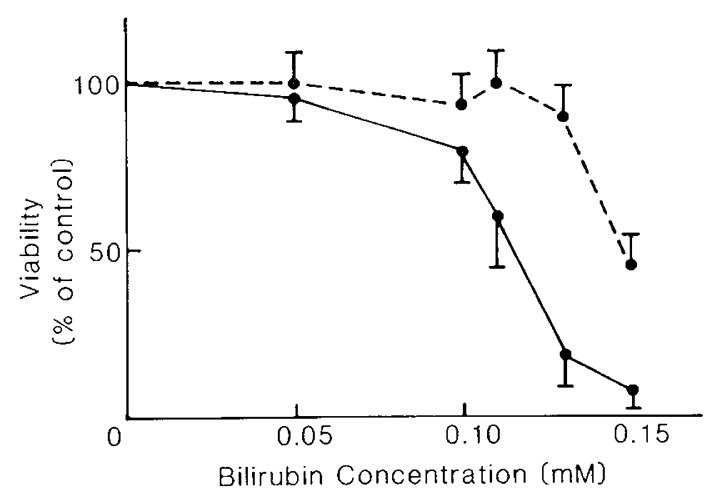

Fig. 1. Albumin concentration is maintained at $0.1 \mathrm{mM}$. The points are compiled as mean \pm 1 SD from absorbances of eight wells. The cells have been incubated with the bilirubin solutions for $22 \mathrm{~h}$ and then incubated with MTT for a further $2 \mathrm{~h}$. NBR10A $\longrightarrow$ N115 - - bilirubin concentrations on cell viability while maintaining a molar ratio of 1.5 and a bilirubin concentration of $0.15 \mathrm{mM}$. At $2 \mathrm{~h}$ the effect of bilirubin on cell viability is minimal, whereas at $24 \mathrm{~h}$ the highest concentration of bilirubin causes the most pronounced effect on viability, less than $10 \%$ of cells remain viable. A similar, but less pronounced affect was seen with N115.

$\left[^{3} H\right]$ thymidine incorporation into DNA. Figures 3 and 4 represent the effect of different concentrations of bilirubin at bilirubin/albumin molar ratios of 0.8 and 1.5 on $\left[{ }^{3} \mathrm{H}\right]$ thymidine incorporation into NBR $10 \mathrm{~A}$ and N115, respectively. Both cell lines respond similarly, i.e. the higher the concentrations of

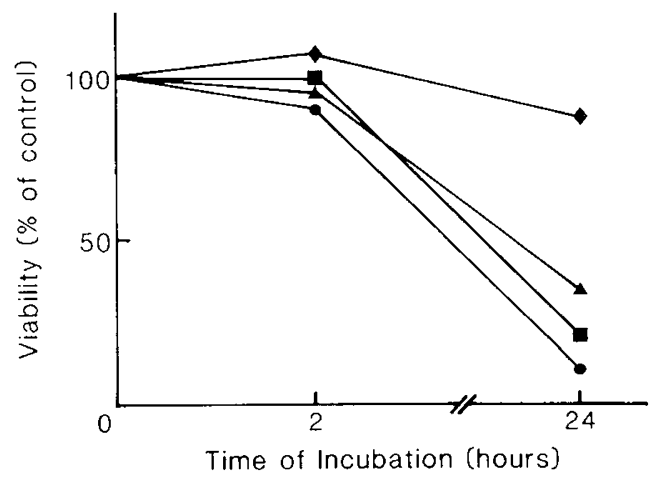

Fig. 2. Cells-NBR10A. $\bigcirc$, albumin $=0.2 \mathrm{mM}$, bilirubin $=$ $0.3 \mathrm{mM} ; \square$, albumin $=0.1 \mathrm{mM}$, bilirubin $=0.15 \mathrm{mM} ; \boldsymbol{\Lambda}-\mathbf{A}$, albumin $=0.05 \mathrm{mM}$, bilirubin $=0.075 \mathrm{mM} \bullet \longrightarrow$, albumin $=0.01$ $\mathrm{mM}$, bilirubin $=0.015 \mathrm{mM}$. The cells are incubated with the above solutions for 2 and $22 \mathrm{~h}$ and then incubated with MTT for a further $2 \mathrm{~h}$. The points are the mean of eight wells. Absorbances of controls (no bilirubin) are taken to be $100 \%$.

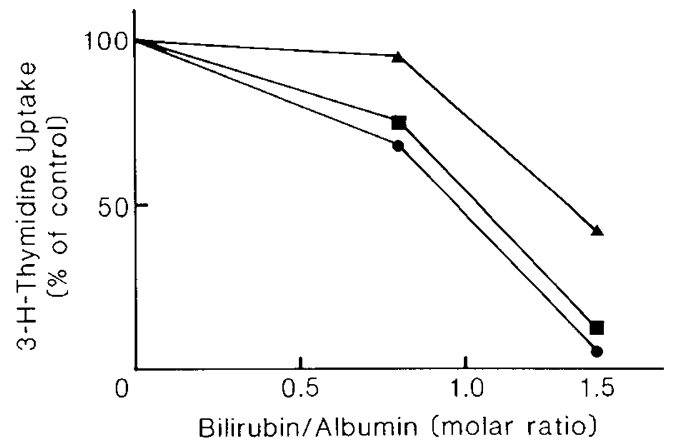

Fig. 3. Cells-NBRI0A. $\longrightarrow$, albumin $=0.2 \mathrm{mM} ; \mathbf{\square}-$ albumin $=0.1 \mathrm{mM} ; \boldsymbol{\Delta} \boldsymbol{\Delta}$, albumin $=0.02 \mathrm{mM}$. The cells are incubated with the bilirubin albumin solutions in experimental media for $22 \mathrm{~h}$ and then pulse labeled with $\left[{ }^{3} \mathrm{H}\right]$ thymidine for a further $2 \mathrm{~h}$.

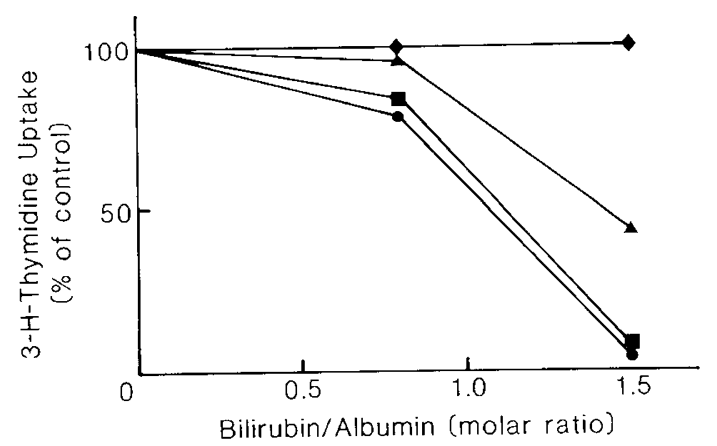

Fig. 4. Cells $-\mathrm{N} 115$. $=0.1 \mathrm{mM} ; \boldsymbol{\Delta} \longrightarrow$, albumin $=0.02 \mathrm{mM} ; \longrightarrow$, albumin $=0.002$ $\mathrm{mM}$. The cells are incubated with the bilirubin albumin solutions in experimental media for $22 \mathrm{~h}$ and then pulse labeled with $\left[{ }^{3} \mathrm{H}\right]$ thymidine for a further $2 \mathrm{~h}$. 
bilirubin, the more suppressed is the $\left[{ }^{3} \mathrm{H}\right]$ thymidine incorporation. The effects of bilirubin are much more pronounced at the higher bilirubin albumin molar ratio. Figure 5 represents the dose response curve obtained from the $\left[{ }^{3} \mathrm{H}\right]$ thymidine incorporation on cell line $\mathrm{N} 115$ at two bilirubin albumin molar ratios, 0.8 and 1.5 , following a $22-\mathrm{h}$ incubation with bilirubin. At high bilirubin to albumin molar ratio (above 1.0), bilirubin is highly toxic at levels as low as $0.010 \mathrm{mM}$, whereas at ratios less than 1.0 , toxicity of bilirubin can only be seen at levels in excess of 0.1 to $0.15 \mathrm{mM}$.

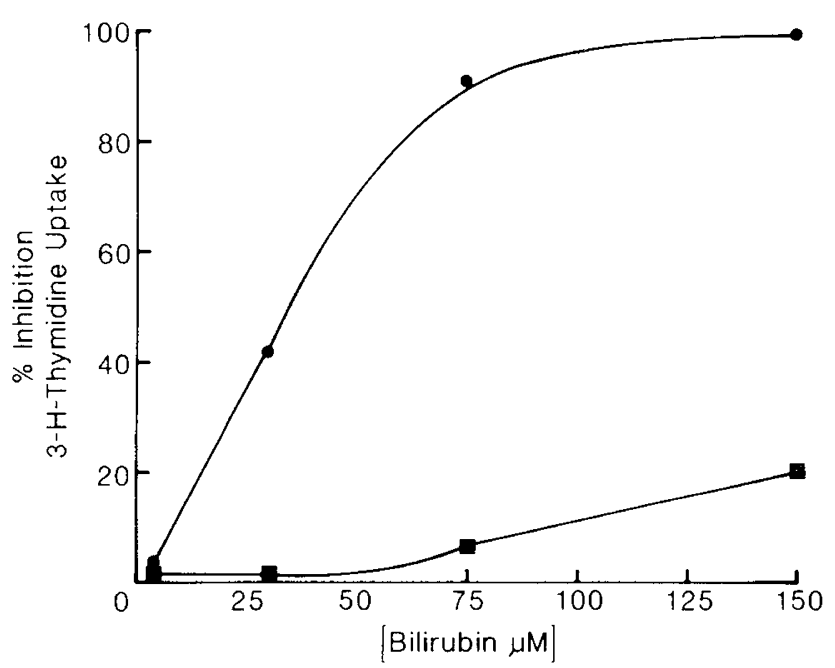

Fig. 5. This figure represents dose response curve for cell line N115. bilirubin-albumin molar ratio of $0.8 ; 0$, bilirubin-albumin molar ratio of 1.5 . Cells have been incubated with the bilirubin-albumin solution in experimental media for $22 \mathrm{~h}$ and then pulse labeled with $\left[{ }^{3} \mathrm{H}\right]$ thymidine for a further $2 \mathrm{~h}$.
Table 1 outlines in detail the raw data from which the figures are derived. In addition, the effect of bilirubin on DNA content as well as specific activity, is included for both cell lines. For example, with N115 cells at a bilirubin/albumin molar ratio of 0.8 and bilirubin concentrations of $0.08 \mathrm{mM}$, there is no change in DNA content, but there is a decrease in specific activity. Whereas at molar ratio of 1.5 and bilirubin concentrations of $0.03 \mathrm{mM}$, there is a decrease in the DNA content and specific activity.

Figure 6 shows the changes in total bilirubin levels during the

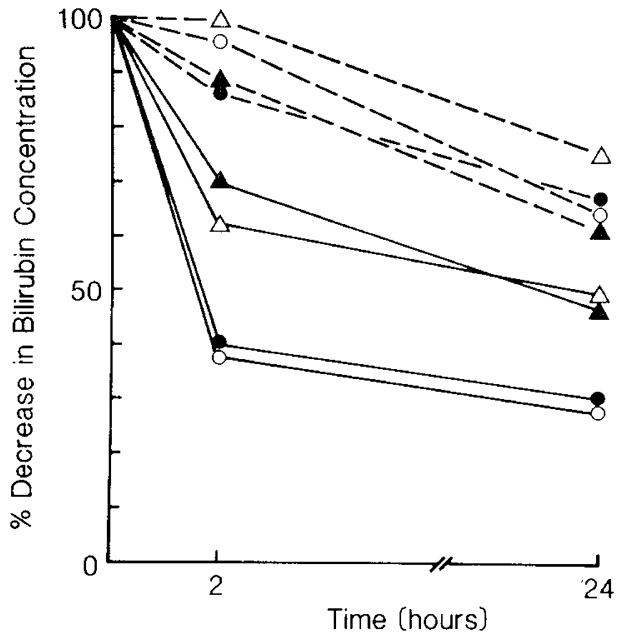

Fig. 6. Cells-N115. $\triangle-\cdots \Delta$, albumin $=0.1 \mathrm{mM}$, bilirubin $=0.08$ $\mathrm{mM} ; \mathrm{O}_{---} \mathrm{O}$, albumin $=0.1 \mathrm{mM}$, bilirubin $=0.15 \mathrm{mM} ; \boldsymbol{\Delta}_{----\Lambda}$, albumin $=0.05 \mathrm{mM}$, bilirubin $=0.04 \mathrm{mM} ;-\ldots$, albumin $=0.05$ $\mathrm{mM}$, bilirubin $=0.075 \mathrm{mM}$. The bilirubin concentrations are done on the media at 0,2 , and $24 \mathrm{~h}$ after incubation with (- - ) and without ($-\infty)$ cells.

Table 1. Effect of bilirubin on $\beta$ H]thymidine incorporation into DNA*

\begin{tabular}{|c|c|c|c|c|c|}
\hline $\begin{array}{c}\text { Bilirubin } \\
\text { concentration } \\
(\mathrm{mM})\end{array}$ & $\begin{array}{l}\text { Albumin } \\
\text { concentration } \\
(\mathrm{mM})\end{array}$ & $\mathrm{cpm}$ & DNA $(\mu \mathrm{g})$ & $\begin{array}{l}\text { Specific activity } \\
(\mathrm{cpm} / \mu \mathrm{g} \text { DNA })\end{array}$ & $\%$ Control \\
\hline \multicolumn{6}{|l|}{ NBR 10A } \\
\hline 0.00 & 0.20 & $3695 \pm 122$ & $12.5 \pm 0.5$ & $295 \pm 16$ & 100 \\
\hline 0.16 & 0.20 & $2145 \pm 490$ & $10.5 \pm 0.8$ & $201 \pm 39$ & 68 \\
\hline 0.30 & 0.20 & $28 \pm 11$ & $1.8 \pm 0.3$ & $16 \pm 4$ & 5 \\
\hline 0.00 & 0.10 & $3922 \pm 805$ & $9.6 \pm 0.7$ & $414 \pm 104$ & 100 \\
\hline 0.08 & 0.10 & $3338 \pm 335$ & $11 \pm 0.4$ & $303 \pm 21$ & 73 \\
\hline 0.15 & 0.10 & $94 \pm 8$ & $2.3 \pm 0.5$ & $42 \pm 11$ & 10 \\
\hline 0.00 & 0.05 & $5019 \pm 360$ & $11.6 \pm 0.4$ & $431 \pm 19$ & 100 \\
\hline 0.04 & 0.05 & $4847 \pm 709$ & $11.9 \pm 0.4$ & $407 \pm 55$ & 94 \\
\hline 0.075 & 0.05 & $1614 \pm 243$ & $7.7 \pm 0.7$ & $209 \pm 15$ & 49 \\
\hline 0.00 & 0.02 & $5623 \pm 439$ & $11.4 \pm 0.4$ & $487 \pm 12$ & 100 \\
\hline 0.016 & 0.02 & $5374 \pm 802$ & $11.7 \pm 0.5$ & $459 \pm 51$ & 94 \\
\hline 0.03 & 0.02 & $2273 \pm 178$ & $11.4 \pm 2$ & $202 \pm 21$ & 42 \\
\hline \multicolumn{6}{|l|}{ N115 } \\
\hline 0.00 & 0.10 & $31760 \pm 8572$ & $17.8 \pm 1.3$ & $1767 \pm 347$ & 100 \\
\hline 0.08 & 0.10 & $22976 \pm 5545$ & $17.1 \pm 1.7$ & $1336 \pm 204$ & 76 \\
\hline 0.15 & 0.10 & $381 \pm 154$ & $3.9 \pm 0.2$ & $100 \pm 45$ & 6 \\
\hline 0.00 & 0.05 & $36705 \pm 3494$ & $17.6 \pm 0.3$ & $2088 \pm 176$ & 100 \\
\hline 0.04 & 0.05 & $32259 \pm 6670$ & $17.1 \pm 0.7$ & $1895 \pm 430$ & 91 \\
\hline 0.075 & 0.05 & $1759 \pm 444$ & $7.8 \pm 0.6$ & $223 \pm 40$ & 11 \\
\hline 0.00 & 0.02 & $31575 \pm 2320$ & $18.0 \pm 0.4$ & $1766 \pm 109$ & 100 \\
\hline 0.016 & 0.02 & $30368 \pm 6446$ & $17.9 \pm 1.0$ & $1711 \pm 342$ & 97 \\
\hline 0.03 & 0.02 & $8884 \pm 3492$ & $12.1 \pm 1.1$ & $721 \pm 219$ & 41 \\
\hline 0.00 & 0.002 & $37172 \pm 4180$ & $17.8 \pm 1.3$ & $2095 \pm 220$ & 100 \\
\hline 0.003 & 0.002 & $36776 \pm 2172$ & $17.7 \pm 0.2$ & $2022 \pm 96$ & 97 \\
\hline
\end{tabular}

* The cells are incubated with the bilirubin-albumin solution as indicated for $22 \mathrm{~h}$ and then pulse labeled with $\left[{ }^{3} \mathrm{H}\right]$ thymidine $(1 \mu \mathrm{Ci}$ per dish) for a further $2 \mathrm{~h}$. Note that in both cell lines there is increase in toxicity at the same molar ratios when both the bilirubin and albumin concentrations are simultaneously increased. 
course of the experiments, i.e. from 0 to $24 \mathrm{~h}$ in the presence or absence of N115 neuroblastoma cells. Even when incubated in the dark at $37^{\circ} \mathrm{C}$ there was a decrease of 20 to $30 \%$ in bilirubin concentration when no cells were present. The decrease in bilirubin levels was more accentuated in experiments with cells (up to $60 \%$ ) especially at higher bilirubin to albumin molar ratios.

The $\mathrm{pH}$ of the experimental media was the same as standard DMEM ( $\mathrm{pH}$ 8.1). Upon addition of bilirubin complexed with albumin to the media containing cells, the $\mathrm{pH}$ was 8.4 and stabilized to $\mathrm{pH}$ of 7.5 by $2 \mathrm{~h}$ and falls to a final pH of 7.3 by 24 $\mathrm{h}$. In the absence of cells, no change in $\mathrm{pH}$ was observed at $2 \mathrm{~h}$ and a slight drop to $\mathrm{pH} 8.2$ by $24 \mathrm{~h}$. The concentration of bilirubin with respect to albumin did not influence the changes in $\mathrm{pH}$. An attempt to measure free bilirubin in the media by the horseradish peroxidase method (11) was made. The results, however, were inconclusive presumably due to the presence of interfering substances in the media.

\section{DISCUSSION}

The solubility of bilirubin has been estimated to be as low as $7 \mathrm{nM}$ in aqueous media at physiological $\mathrm{pH}$ and a temperature of $37^{\circ} \mathrm{C}(12,13)$. The low solubility makes it inappropriate to study the cytotoxic effects of bilirubin in protein-free media in monolayer tissue culture cell systems such as the cell lines used in the experiments. To investigate the relationship of albumin and bilirubin on these two neural cell lines, the cells are adapted to a protein-free medium in which they seem to thrive quite well during the course of the experiments.

The MTT assay provides a simple quantitative method for the assessment of cell viability to bilirubin toxicity on cells in culture. The results obtained by this approach were supported by $\left[{ }^{3} \mathrm{H}\right]-$ thymidine incorporation studies that bilirubin has little or no toxic effect in short-term incubations $(2 \mathrm{~h})$ at bilirubin-albumin molar ratios of up to 1.5 and bilirubin concentrations from 0.3 to $0.015 \mathrm{mM}$ in both NBR $10 \mathrm{~A}$ and N115 cells. Longer exposure time $(24 \mathrm{~h})$ to bilirubin under the same conditions resulted in a decrease in viability (Fig. 2), a decrease in specific activity (cpm/ $\mu \mathrm{g}$ DNA) and a decrease in DNA levels (Table 1) relative to the bilirubin-albumin molar ratio and the absolute bilirubin levels. It was observed that when the bilirubin-containing media were removed after $2 \mathrm{~h}$ and the cells were incubated with fresh media containing no bilirubin for a further $22 \mathrm{~h}$, an improvement in viability at $24 \mathrm{~h}$ was noted suggesting bilirubin toxicity in these cells is a time-related event.

It is of interest to note that with NBR10A cells (Table 1) the higher albumin concentration in the media without bilirubin had an adverse effect on $\left.{ }^{3} \mathrm{H}\right]$ thymidine incorporation suggesting less than optimal conditions for growth for this cell line. This observation may explain in part the increase susceptibility of those cells to bilirubin cytotoxicity.

Bilirubin is chemically unstable in alkaline solution and undergoes autooxidation (14). Complexed with albumin, the decomposition of bilirubin is slowed down but still occurred under the conditions in the incubator (Fig. 6). The further decrease in bilirubin concentration in the media when cells were present can be explained on the basis of a decrease in $\mathrm{pH}$, oxidation, uptake by the cells as evident by the yellow staining when they were harvested, or as in the case of the higher molar ratio of bilirubin to albumin, precipitation and aggregation of the pigment to the walls of the container. The influence of a decrease in $\mathrm{pH}$ on tissue binding or toxicity of bilirubin was observed in red blood cells (15), mitochondria (16), and cerebellar culture cells (2), while tissue culture cells such as L-929 cells (5) seemed less susceptible to bilirubin toxicity when the $\mathrm{pH}$ was lowered from 7.4 to 7.0 . It is doubtful whether a decrease from $\mathrm{pH} 7.5$ to $\mathrm{pH}$ 7.3 in $24 \mathrm{~h}$ was a contributing factor in cell viability in the present experiments.

The binding affinity of human serum albumin for bilirubin is very high at the primary site of binding $(12,17,18)$. An additional 1 or $2 \mathrm{~mol}$ of bilirubin can also bind but with less tenacity than the first. The lack of a toxic response to bilirubin bound tightly to albumin even at high bilirubin levels ( $160 \mu \mathrm{mol} / \mathrm{liter})$ concurs with results reported by Lie and Bratlid (3) working with fibroblasts and at variance with those of Thaler (6) in hepatoma cells. This could be explained by the different responses of cells to bilirubin, as reported in this study and as previously reported by Pramanik and Horn (19) who showed variation in cellular uptake of bilirubin depending on cell type.

The neural cell lines used in the experiments are of neuroblastoma origin and may therefore react quite differently than normal nerve cells to bilirubin toxicity. The ease to propagate and the homogeneity of the cultured cells provides the grouncwork in setting up the methodology for studies of primary brain culture cells which we will be pursuing in the near future. The question of whether "free" or "loosely bound" bilirubin is the driving force in the pathogenesis of bilirubin encephalopathy is still a matter of debate $(20-22)$.

Acknowledgments. The authors thank Dr. A. McDonagh, University of California, San Francisco for performing the HPLC analysis of the bilirubin preparation. We are grateful to Deanna Moores for technical assistance and to Fern Nielsen for secretarial skills.

\section{REFERENCES}

1. Bernstein J, Landing BH 1962 Extraneural lesions associated hyperbilirubinemia and kernicterus. Am J Pathol 40:371-391

2. Silberberg DH, Johnson L. Ritter L 1970 Factors influencing toxicity of bilirubin in cerebellum tissue culture. J Pediat 77:386-396

3. Lie SD, Bratlid D 1970 The protective effect of albumin on bilirubin toxiciry on human fibroblasts. Scand J Lab Invest 26:37-41

4. Rasmussen F, Wennberg R 1972 Pharmacologic modification of bilirubin toxicity in tissue culture cells. Res Commun Chem Pathol Pharmacol 3:567578

5. Cowger ML 1971 Mechanism of bilirubin toxicity on tissue culture cells: factors that affect toxicity, reversibility by albumin and comparison with other respiratory poisons and surfactants. Biochem Med 5:1-16

6. Thaler MM 1971 Bilirubin toxicity in hepatoma cells. Nature New Biol $230: 218-219$

7. Mosmann $\Upsilon 1983$ Rapid colorimetric assay for cellular growth and survival: application to proliferation and cytotoxicity assays. J Immunol Meth 65 : $55-63$

8. Yavin Z. Yavin E, Kohn LD 1982 Sequestration of tetanus toxin in developing neuronal cell cultures. J Neurol Sci Res 7:267-278

9. Burton K 1968 Determination of DNA concentration with diphenylamine. In: Grossman L, Moldave K (eds) Methods in Enzymology, Vol 12B. Academic Press, New York, pp 163-166

10. Martinek RG 1966 Improved micromethod for determination of serum bilirubin. Clin Chim Acta 13:161-170

11. Jacobsen J, Wennberg RP 1974 Determination of unbound bilirubin in serum of newborns. Clin Chem 20:783-789

12. Brodersen R 1979 Bilirubin solubility and interaction with albumin and phospholipid. J Biol Chem 254:2364-2369

13. Brodersen R 1982 Physical chemistry of bilirubin: binding to macrolecules and membranes. In: Heinwegh KPM, Brown SB (eds) Bilirubin, Vol 1. Chemistry CRC Press, Boca Baton, FL, pp 77-91

14. Lightner DA, Cu A, McDonagh AF, Palma LA 1976 On the autooxidation of bilirubin. Biochem Biophys Res Commun 69:648-657

15. Bradlid D 1972 The effect of $\mathrm{pH}$ on bilirubin binding by human erythrocytcs. Scand J Clin Lab Invest 29:453-459

16. Odell GB 1965 Influence of $\mathrm{pH}$ on the distribution of bilirubin between albumin and mitochondria. Proc Soc Exp Biol Med 120:352-354

17. Jacobsen J 1969 Binding of bilirubin to human serum albumin, determination of the dissociation constants. FEBS Lett 5:112-114

18. Wennberg RP, Ahlfors CE. Rasmussen F $1979^{\text {Th }}$ The pathochemistry of kernicterus. Early Hum Dev 3:353-372

19. Pramanik AK, Horn NA 1979 Differential toxic response of human tissue culture systems to bilirubin. Clin Res 27:128A(abstr)

20. Levine RL, Fredericks NR, Rapport SI 1982 Entry of bilirubin into the brain due to opening of the blood brain barrier. Pediatrics 69:255-259

21. Ritter DA Kenny JD Norton HJ, Rudolph RJ 1982 A prospective study for free bilirubin and other risk factors in the development of kernicterus in premature infants. Pediatrics 69:260-266

22. Turkel SB, Miller CA Guttenberg ME, Moynes OR, Hodgman JE 1982 A clinical pathologic reappraisal of kernicterus. Pediatrics 69:267-272 